\title{
Perbandingan Model Pembelajaran Direct Intruction (DI) dengan Model Pembelajaran Kooperatif Tipe Numbered Head Together (NHT) Kemampuan Komunikasi Matematis Siswa
}

\author{
Sri Wildaningsih, Ejen Jenal Mutaqin, Neni Nadiroti Muslihah
}

Institut Pendidikan Indonesia

sriwidaniningsih81@gmail.com

\section{Article History}

accepted 2/11/2019

approved 23/11/2019

published 31/12/2019

\begin{abstract}
Mathematical communication skills are very important possessed by students, but in reality are still relatively low. One of the factors that influence it is the lack of variety of learning models in the classroom. In response to this, there are two models as solutions, namely the Direct Instruction (DI) Learning Model with the Numbered Head Together (NHT) Cooperative Learning Model. The aim is to analyze the improvement in mathematical communication skills of students who get the DI learning model and the NHT type cooperative learning model, and analyze the mathematical communication skills. The method used in this study is quasi-experimental, with a population of all students in SDN 1 Mekarsari, and the sample is class IV A as experimental class 1 and class IV B as experimental class 2. Quantitatively, the results of experimental class 1 research show interpretation moderate increase (average gain $=0.37$ ). And the experimental class 2 shows the interpretation of a moderate increase (average gain $=0.58$ ). Based on these two results, the NHT type of cooperative.
\end{abstract}

Keywords: Mathematical Communication, Direct Instruction, Numbered Head Together

\begin{abstract}
Abstrak
Kemampuan komunikasi matematis sangat penting dimiliki oleh siswa, namun pada kenyataannya masih tergolong rendah. Salah satu faktor yang mempengaruhinya adalah kurang variatifnya model pembelajaran di kelas. Menanggapi hal tersebut, terdapat dua model yang sebagai solusi, yaitu Model Pembelajaran Direct Instruction (DI) dengan Model Pembelajaran Kooperatif Tipe Numbered Head Together (NHT). Tujuannya untuk menganalisis peningkatan kemampuan komunikasi matematis siswa yang mendapat model pembelajran DI dan model pembelajaran kooperatif tipe $\mathrm{NHT}$, dan menganalisis kemampuan komunikasi matematis tersebut. Metode yang digunakan dalam penelitian ini yaitu kuasi eksperimen, dengan populasi seluruh siswa-siswi di SDN 1 Mekarsari, dan sampel yaitu kelas IV A sebagai kelas eksperimen 1 dan kelas IV B sebagai kelas eksperimen 2. Secara kuantitatif, hasil penelitian kelas eksperimen 1 menunjukan interpretasi peningkatan sedang (rata-rata gain $=0,37$ ). Dan kelas eksperimen 2 menunjukan interpretasi peningkatan sedang (rata-rata gain $=0,58$ ). Berdasarkan kedua hasil penelitian tersebut maka model pembelajaran kooperatif tipe NHT lebih baik daripada model pembelajaran DI.
\end{abstract}

Kata kunci: Komunikasi Matematis, Direct Intruction, Numbered Head Together

Social, Humanities, and Education Studies (SHEs): Conference Series https://jurnal.uns.ac.id/shes

p-ISSN 2620-9284 e-ISSN 2620-9292 


\section{PENDAHULUAN}

Matematika sebagai ilmu dasar memiliki peranan penting dalam pengembangan ilmu pengetahuan dan teknologi salah satunya yaitu pengembangan komunikasi matematis. Permendiknas No 22 tahun 2006 menjelaskan "salah satu target dalam pembelajaran matematika adalah tumbuhnya kemampuan siswa dalam mengomunikasikan ide atau pokok pikiran dalam bentuk simbol, tabel,diagram,atau media lain untuk menggambarkan keadaan atau masalah" (Depdiknas, 2006, hlm. 146). Kemampuan komunikasi matematis merupakan salah satu proses penting dalam pembelajaran matematika, dengan kemampuan komunikasi siswa akan mampu memecahkan masalah, menemukan pola yang kemudian dituangkan ke dalam bentuk simbol matematika.

Menurut Lestari dan Yudhanegara (2015) kemampuan komunikasi matematis adalah kemampuan menyampaikan gagasan/ide matematis, baik secara lisan maupun secara tulisan serta kemampuan memahami dan menerima gagasan/ide matematis orang lain secara cermat, analitis, kritis dan evaluatif untuk mempertajam pemahaman. (hlm. 83).

Berdasarkan penelitian yang dilakukan oleh Kadir (Hayati, 2014) yang menyebutkan bahwa komunikasi matematis siswa masih rendah, antara lain:

1. Secara umum siswa tidak dapat menjawab pertanyaan lanjutan dari sebuah soal yang masih memerlukan informasi tambahan

2. Siswa belum dapat membuat model matematika dari sebuah masalah non rutin yang melibatkan bilangan pecahan, hal ini berdampak pada siswa tidak dapat me1mecahkan soal yang diberikan

3. Masih banyak siswa yang dapat membuat model matematika dari suatu soal yang disusun dalam bentuk tabel dengan susunan yang tidak biasa.

4. Masih banyak siswa yang salah dalam melakukan perkalian antara suatu bilangan dengan sebuah persamaan

5. Masih banyak siswa yang salah dalam menentukan bilangan pengali untuk menyelesaikan suatu model matematika dengan metode eliminasi

6. Masih ada siswa yang belum dapat menuliskan jawaban akhir sebagai solusi dari suatu masalah.

Pernyataan tersebut sesuai dengan hasil awal melalui wawancara yang dilakukan dengan salah satu guru matematika kelas 4 SDN 1 Mekarsari pada tanggal 24 Maret 2019, bahwa kemampuan komunikasi matematis siswa masih kurang sehingga belum mencapai KKM dengan nilai terendah yang diperoleh adalah 40 . Dari hasil tersebut dapat disimpulkan, bahwa siswa memiliki kemampuan komunikasi yang rendah. Rendahnya komunikasi siswa karena pembelajaran yang bersifat konvensional, berpusat pada guru, siswa kurang aktif dalam pembelajaran dalam kelas.

Rendahnya tingkat komunikasi matematis siswa di lapangan perlu mendapatkan perhatian yang lebih dari berbagai pihak, khususnya bagi guru itu sendiri. Pemilihan model pembelajaran pada mata pelajaran matematika sangatlah penting, terutama untuk siswa SD. Dengan demikian, seorang guru harus mampu memiliki kreativitas agar siswa dapat berperan aktif dalam kegiatan pembelajaran dan proses pembelajaran lebih terarah. Adapun model pembelajaran yang dapat dijadikan solusi adalah model pembelajaran Direct Intruction (DI) dan model pembelajaran kooperatif tipe Numbered Head Together (NHT) untuk dapat meningkatkan komunikasi matematis siswa.

Berdasarkan uraian di atas, mendorong penulis untuk melakukan penelitian dengan judul penelitian "Perbandingan Model Pembelajaran Direct Intruction (DI) Dengan Model Pembelajaran Kooperatif Tipe Numbered Head Together (DI) Kemampuan Komunikasi Matematis Siswa" 
Berdasarkan latar belakang masalah di atas, maka rumusan masalah yang diajukan dalam penelitian ini antara lain:

1. Apakah terdapat peningkatan kemampuan komunikasi matematis siswa yang mendapat model pembelajaraan Direct Intruction (DI)?

2. Apakah terdapat peningkatan kemampuan komunikasi matematis siswa yang mendapat model pembelajaraan kooperatif tipe Numbered Head Together $(N H T)$ ?

3. Bagaimana kemampuan komunikasi matematis siswa yang mendapat model pembelajaran kooperatif tipe Numbered Head Together (NHT) lebih baik daripada siswa yang mendapat model pembelajaran Direct Intruction (DI)

Adapun tujuan dalam penelitian ini adalah untuk mengetahui peningkatan kemampuan komunikasi matematis siswa yang mendapat model pembelajran Direct Instruction (DI), untuk mengetahui peningkatan kemampuan komunikasi matematis siswa model pembelajaran kooperatif tipe Numbered Head Together (NHT), untuk menganalisis kemampuan komunikasi matematis siswa yang lebih baik antara yang mendapatkan model pembelajaran Direct Intruction (DI) dengan model pembelajaran kooperatif tipe Numbered Head Together (NHT).

\section{Kemampuan Komunikasi Matematis Siswa}

Lestari dan Yudhanegara (2015) mengatakan bahwa kemampuan komunikasi matematis adalah kemampuan menyampaikan gagasan/ide matematis, baik secara lisan maupun secara tulisan serta kemampuan memahami dan menerima gagasan/ide matematis orang lain secara cermat, analitis, kritis dan evaluatif untuk mempertajam pemahaman.

Sedangkan menurut Suherman (Hibatulloh dan Sofyan, 2014) menyatakan bahwa kemampuan komunikasi matematis adalah kemampuan siswa untuk mengomunikasikan ide matematik kepada orang lain, dalam bentuk lisan, tulisan atau diagram sehingga orang lain memahaminya. Penelitian mengenai komunikasi matematis siswa didasarkan pada beberapa indikator yang peneliti jadikan sebagai acuan dalam pembuatan soal. Indikator-indikator tersebut menurut Sinaga (2017, hlm. 6) adalah sebagai berikut:

1. Menghubungkan benda nyata, gambar, dan diagram ke dalam ide matematika

2. Menjelaskan ide, situasi, dan relasi matematika secara lisan atau tulisan, dengan benda nyata, gambar, grafik, dan aljabar

3. Menyatakan peristiwa sehari-hari dalam bahasa simbol matematika

4. Mendengarkan, berdiskusi, dan menulis tentang matematika

\section{Model Pembelajaran Direct Instruction (DI)}

Menurut Joyce, Weil, dan Calhoun (2016) model pembelajaran Direct Instruction (DI) adalah model pembelajaran yang berpusat kepada guru, dimana guru merancang suatu pembelajaran yang berfokus kepada tujuan-tujuan dan tugas-tugas yang telah ditetapkan sebelumnya, serta memastikan adanya pemahaman siswa terhadap masing-masing konsep. Menurut Lestari dan Yudhanegara (2015) tahapan model pengajaran langsung tersebut disajikan dalam lima tahap, yaitu fase orientasi, fase presentase atau demonstrasi, fase latihan terstruktur, fase terbimbing, fase latihan mandiri.

Kelebihan dari model ini yaitu dapat diterapkan secara efektif dalam kelas yang besar maupun kecil dan dapat membantu kesulitan-kesulitan yang mungkin dihadapi siswa sehingga hal-hal tersebut dapat diungkapkan. Adapun kekurangan dari model ini yaitu Peran guru sangat penting dalam pembelajaran (learning center), dan ini menimbulkan kesuksesan pembelajaran siswa bergantung pada gurunya. 


\section{Model Pembelajaran Kooperatif Tipe Numbered Head Together}

Model pembelajaran kooperatif tipe Numbered Head Together (NHT) adalah model pembelajaran yang dikembangkan oleh Spencer Kagan (1992) yang mengharuskan siswa untuk melakukan kerjasama dengan siswa lainnya.

Menurut Spencer Kagan (Komalasari, 2015, hlm. 62) "model pembelajaran kooperatif tipe Numbered Head Together (NHT) adalah model pembelajaran dimana setiap siswa diberi nomor kemudian dibuat suatu kelompok secara acak guru memanggil nomor dari siswa"

Kelebihan model pembelajaran ini yaitu setiap siswa berkesempatan untuk berekspresi dan mengeluarkan pendapatnya. Siswa berkesempatan mengemukakan pendapat ketika kegiatan pembelajaran. Adapun kekurangan dari model pembelajaran ini yaitu memerlukan alokasi waktu yang panjang.

Melalui penerapan model pembelajaran $D I$ dan model pembelajaran kooperatif tipe NHT diharapkan dapat meningkatkan kemampuan komunikasi matematis siswa dalam berargumentasi, berdiskusi dengan temannya, dan berpartisipasi aktif dengan mengekspresikan idenya dengan bahasa sendiri.

\section{METODE}

Dalam penelitian ini, metode yang digunakan oleh peneliti adalah model kuasi eksperimen. Desain yang digunakan dalam penelitian ini yaitu

$\begin{array}{ccc}01 & \mathrm{X} 1 & \mathrm{O} \\ 01 & \mathrm{X} 2 & 02\end{array}$

Keterangan:

$\mathrm{O} 1=$ Kegiatan pengujian instrument pretest
$\mathrm{O} 2=$ Kegiatan pengujian instrument posttest
$\mathrm{X} 1=$ Pembelajaran dengan model pembelajaran Direct Instruction
$\mathrm{X} 2=$ Pembelajaran dengan menggunakan model pembelajaran kooperatif
tipe Numbered Head Tegether

(Sukmadinata, 2015, hlm. 208)

Pada penelitian ini, populasi penelitian yaitu seluruh siswa-siswi di SDN 1 Mekarsari dengan jumlah 328 siswa.Sampel dalam penelitian ini adalah siswa kelas IV SDN 1 Mekarsari dan yang menjadi sampel dari penelitian ini adalah dua kelas yang diberikan oleh sekolah yang terdiri dari kelas eksprerimen I untuk model pembelajaran Direct Instruction (DI) yaitu kelas IV A sebanyak 28 siswa dan kelas eksperimen II untuk model pembelajaran kooperatif tipe Numbered Head Together (NHT) yaitu kelas IV B sebanyak 30.

Adapun teknik pengumpulan data dan instrument penelitian yang digunakan adalah sebagai berikut: 1) Teknik pengumpulan data berupa tes; 2) Teknik pengumpulan data observasi. Serta waktu Pelaksanaan penelitian yaitu dari tanggal 13-27 bulan April tahun pelajaran 2018-2019

Gambaran terhadap data yang telah dikumpulkan dari hasil penelitian maka dilakukan analisis data. Hal ini dimaksudkan untuk mencari kesimpulan dan menguji hipotesis. Data yang dianalisis diperoleh dari hasil pretest dan posttest. Adapun langkah-langkah dalam menganalisis data adalah sebagai berikut: 
4th National Seminar on Guidance and Counseling (SNBK 2019) and Workshop on

Pedagogical Theory and Practice (WTPP 2019)

SHEs: Conference Series 2 (2) (2019) $184-192$

Tabel 1 Statistik dalam Penelitian ini

\begin{tabular}{|c|c|}
\hline Analisis Data & Uji Statistik yang \\
\hline \multirow{3}{*}{ Pre-test } & Uji Normalitas \\
\cline { 2 - 2 } & $\begin{array}{c}\text { Uji Kesamaan Kemampuan } \\
\text { Awal (Mann Whitnev) }\end{array}$ \\
\hline \multirow{4}{*}{ Post-test } & Uji Normalitas \\
\cline { 2 - 2 } $\begin{array}{l}\text { Uji Perbandingan (Gain } \\
\text { Ternormalisasi) }\end{array}$ & $\begin{array}{c}\text { Uji Perbedaan Kemampuan } \\
\text { Akhir (Mann Whitney) }\end{array}$ \\
\cline { 2 - 2 } & Uji Normalitas \\
\cline { 2 - 2 } & Uji Homogenitas \\
\hline & Uji Kesaman Kemampuan Awal \\
& (Mann Whitney) \\
\hline
\end{tabular}

Hasil Penelitian

HASIL DAN PEMBAHASAN

Dari hasil penelitian kedua kelas yang mendapatkan model pembelajaran Direct Instruction $(D I)$ untuk kelas eksperimen 1 yaitu kelas IV A dan model pembelajaran kooperatif tipe Numbered Head Together (NHT) pada pokok pembelajaran bahasan pengolahan data. Membedakan kemampuan komunikasi matematis pada dua kelompok ini dilakukan dengan memberikan tes kepada kedua kelompok yaitu kelas IV A dan kelas IV B. Tes yang diberikan antara lain tes awal (Pretest) dan tes akhir (Posttest), sehingga diperoleh hasil seperti tabel 2 dan table 3 berikut :

Tabel 2 Data Kelas Direct Instruction (DI)

\begin{tabular}{lccc}
\hline \multicolumn{1}{c}{ Kelas } & \multicolumn{3}{c}{ Kelas Eksperimen 1 } \\
& Pretest & Posttest & Gain \\
\hline $\begin{array}{l}\text { Jumlah } \\
\text { siswa } \\
\text { Rata-rata }\end{array}$ & 8,43 & 17,05 & 0,37 \\
\hline $\begin{array}{l}\text { Simpangan } \\
\text { Baku }\end{array}$ & 2,35 & 3,36 & 0,13 \\
& & &
\end{tabular}

Tabel 3 Data Kelas Numbered Head Together (NHT) Kelas

Kelas Eksperimen 2

$\begin{array}{ccc}\text { Pretest Posttest } & \begin{array}{c}\text { Gain } \\ \text { Ternormalisasi }\end{array}\end{array}$

$\begin{array}{llll}\begin{array}{c}\text { Jumlah } \\ \text { siswa }\end{array} & & 30 & \\ \text { Rata-rata } & 12,68 & 23,05 & 0,58 \\ \begin{array}{c}\text { Simpangan } \\ \text { Baku }\end{array} & 4,54 & 4,40 & 0,19\end{array}$

Analisis Perbedaan Kemampuan Komunikasi Matematis

Berdasarkan tabel 2 dan 3 diketahui bahwa skor rata-rata kemampuan awal komunikasi matematis pada kelas $\mathrm{DI}$ adalah 8,43 dan simpangan baku 2,35. Sedangkan rata-rata kemampuan awal komunikasi matematis pada kelas NHT adalah 
12,68 dan simpangan baku 4,54. Setelah diuji normalitas, ternyata kedua kelas tidak berdistribusi normal maka dilanjutkan dengan uji non parametrik dengan menggunakan uji Mann Whitney dan diperoleh kesimpulan bahwa terdapat perbedaan kemampuan komunikasi matematis antara siswa yang mendapatkan model pembelajaran $D I$ dengan siswa yang mendapatkan model pembelajaran kooperatif tipe NHT.

Selain itu, berdasarkan tabel 1 dan 2 diketahui bahwa skor rata-rata kemampuan akhir komunikasi matematis pada kelas DI adalah 17,05 dan simpangan baku 3,36. Sedangkan rata-rata kemampuan akhir komunikasi matematis pada kelas NHT adalah 23,05 dan simpangan baku 4,40. Setelah diuji normalitas, ternyata kedua kelas tidak berdistribusi normal maka dilanjutkan dengan uji statistik non parametrik dengan menggunakan uji Mann Whitney kesimpulan bahwa terdapat perbedaan kemampuan akhir komunikasi matematis antara siswa yang mendapatkan model pembelajaran $D I$ dengan siswa yang mendapatkan model pembelajaran NHT.

Berdasarkan tabel 1 dan 2 diketahui bahwa skor rata-rata gain kemampuan komunikasi matematis pada kelas $D I$ adalah 0,37 dan simpangan baku 0,13. Sedangkan rata-rata gain kemampuan komunikasi matematis pada kelas $N H T$ adalah 0,58 dan simpangan baku 0,19. Setelah diuji normalitas, ternyata kedua kelas berdistribusi normal maka dilanjutkan dengan uji homogenitas, karena data tidak homogeny maka dilanjutkan dengan uji t' dengan kesimpulan bahwa kemampuan komunikasi matematis siswa yang mendapatkan model pembelajaran kooperatif tipe NHT lebih baik daripada siswa yang mendapatkan model pembelajaran DI.

\section{Analisis Kualitas Peningkatan Kemampuan Komunikasi Matematis}

Informasi mengenai peningkatan kemampuan pemecahan masalah matematis siswa pada kelas $D I$ dan kelas NHT diperoleh dari hasil sebagai berikut: skor gain ternormalisasi. Berdasarkan hasil perhitungan gain ternormalisasi kelas $N H T$ dan kelas $D I$, maka diperoleh.

Tabel 4 Hasil Gain Ternormalisasi

\begin{tabular}{|c|c|c|c|c|c|}
\hline \multirow{2}{*}{ No. } & $\begin{array}{c}\text { Interpretasi Gain } \\
\text { Ternormalisasi }\end{array}$ & \multicolumn{2}{|c|}{ DI } & \multicolumn{2}{|c|}{ NHT } \\
\cline { 3 - 6 } & & fi & Presentase (\%) & fi & Presentase (\%) \\
\hline 1 & Tinggi & 0 & 0 & 4 & 13,33 \\
\hline 2 & Sedang & 19 & 68 & 25 & 83,33 \\
\hline 3 & Rendah & 9 & 32 & 1 & 3,33 \\
\hline & Jumlah & 28 & 100 & 30 & 100 \\
\hline
\end{tabular}

Berdasarkan tabel di atas, diketahui bahwa secara umum kualitas peningkatan kemampuan komunikasi matematis siswa kelas $D I$ maupun $N H T$ berada pada kategori sedang.

\section{Pembahasan}

Berdasarkan hasil analisis Gain Ternormalisasi, penerimaan hipotesis alternatif pada uji perbedaan kemampuan komunikasi matematis siswa menunjukkan bahwa adanya model pembelajaran kooperatif tipe $N H T$ lebih baik daripada yang menggunakan model pembelajaran $D I$.

Peneliti beranggapan bahwa terdapat faktor penyebab kemampuan komunikasi matematis siswa yang mendapatkan model pembelajaran kooperatif tipe NHT lebih baik daripada siswa yang mendapatkan model pembelajaran $D I$, antara lain :

a. Tingkat kecerdasan/intelegensi. Pada kelas eksperimen 1, rata-rata 
peningkatan kemampuan komunikasi yang meningkat dua kali lebih baik dari rata-rata pretest dan $68 \%$ siswa memiliki tingkat peningkatan yang sedang serta $32 \%$ siswa memiliki tingkat peningkatan yang rendah. Berbeda dengan kelas eksperimen 2, rata-rata peningkatan kemampuan komunikasi yang meningkat lebih baik dari rata-rata pretest dengan 13,33\% siswa memiliki tingkat peningkatan yang tinggi, $83,33 \%$ siswa tingkat peningkatan sedang serta $3,33 \%$ siswa memiliki tingkat peningkatan yang rendah. Dilihat dari tingkat kecerdasan atau intelegensi kelas eksperimen 2 yang mendapat model pembelajaran $N H T$ lebih baik daripada kelas eksperimen 1 yang mendapat model pembelajaran $D I$.

b. Sikap siswa. Pada kelas eksperimen 1 sebagian siswa memperhatikan dengan baik meskipun ada siswa yang tidak memperhatingan dan bahkan mengganggu orang lain. Selain itu, ketika proses pembelajaran siswa juga aktif untuk tampil ke depan meskipun pada awalnya mereka tidak berani karena malu. Sedangkan kelas eksperimen 2, siswa memperhatikan dengan baik dan tidak mengganggu orang lain, dan proses pembelajaran siswa juga sangat aktif untuk tampil ke depan. Dilihat dari sikap siswa kelas eksperimen 2 yang mendapat model pembelajaran NHT lebih baik daripada kelas eksperimen 1 yang mendapat model pembelajaran $D I$.

c. Minat siswa. Pada kelas eksperimen 1, minat siswa dalam matematika terbilang cukup, dalam proses pembelajaran siswa bersungguh-sungguh dalam belajar namun ada juga siswa yang tidak fokus dan menggangu siswa yang lainnya. Sedangkan, pada kelas eksperimen 2, minat siswa dalam matematika terbilang baik, karena dalam proses pembelajaran siswa fokus mendengarkan dan bersungguh-sungguh dalam mengerjakan tugas yang diberikan oleh guru. Dilihat dari minat siswa kelas eksperimen 2 yang mendapat model pembelajaran NHT lebih baik daripada kelas eksperimen 1 yang mendapat model pembelajaran $D I$.

d. Motivasi belajar. Motivasi belajar pada kelas eksperimen terbilang baik, semua siswa pada awalnya malu untuk belajar dan canggung, namun setelah itu mereka mulai terbiasa dan semangat untuk belajar karena adanya media pembelajaran yang membuat siswa tertarik.

e. Motivasi belajar pada kelas eksperimen 2 terbilang baik, semua siswa pada awalnya malu untuk belajar dan canggung, namun setelah itu mereka mulai terbiasa dan semangat untuk belajar karena pembelajaran NHT menuntut siswa mampu mengomunikasikan gagasan yang mereka miliki terkait materi yang sedang dipelajari. Dilihat dari motivasi belajar kelas eksperimen 2 yang mendapat model pembelajaran $N H T$ lebih baik daripada kelas eksperimen 1 yang mendapat model pembelajaran DI karena siswa dituntut untuk mampu mengomunikasikan gagasan yang mereka miliki terkait materi yang sedang dipelajari.

f. Penggunaan media pembelajaran. Pada kelas eksperimen 1, proses pembelajaran pada pertemuan pertama yaitu menggunakan media kantong ulat, sehingga semua siswa berperan aktif dalam proses pembelajaran dan semangat dalam belajar. Sedangkan pada kelas eksperimen 2, proses pembelajaran pada pertemuan pertama yaitu menggunakan kertas origami dan nomor kepala, sehingga semua siswa berperan aktif dalam proses pembelajaran dan semangat dalam belajar dan bersungguh-sungguh dalam kerja kelompok. Awalnya siswa tidak terbiasa dengan kegiatan diskusi namun mempelajari materi karena siswa harus mengomunikasikan gagasan yang mereka miliki.

g. Penggunaan metode pembelajaran pada kelas eksperimen 1, dalam kegiatan 
evaluasi maka siswa dikumpulkan menjadi beberapa kemudian siswa mulai terbiasa. Berbeda dengan kelas eksperimen 2, dalam kegiatan evaluasi maka siswa dikumpulkan menjadi beberapa kelompok. Mereka sangat antusias melakukan diskusi dan berusaha mendapatkan nilai terbaik.

h. Penggunaan model pembelajaran yang berbeda. Pada kelas eksperimen 1 siswa mendapat perlakukan dengan model pembelajaran Direct Instruction (DI) dimana guru menjadi pengaruh utama terhadap keberhasilan pembelajaran yang dilakukan secara terstruktur dan terbimbing. Dan untuk kelas eksperimen 2 siswa mendapat perlakukan dengan model pembelajaran kooperatif tipe Numbered Head Together (NHT), siswa diberikan kebebasan dalam proses pembelajaran dengan berdiskusi dengan temannya. Sehingga komunikasi matematis model ini lebih baik daripada model pembelajaran Direct Instruction (DI).

\section{SIMPULAN}

Berdasarkan analisis data dan pembahasan hasil penelitian yang telah dikemukakan pada pembahasan sebelumnya, dapat ditarik simpulan sebagai berikut:

1. Peningkatan kemampuan komunikasi matematis siswa kelas eksperimen 1 yang mendapatkan model pembelajaran Direct Instruction (DI) berdasarkan hasil analisis gain ternormalisasi memperoleh nilai rata-rata gain 0,37 dengan interpretasi peningkatan sedang.

2. Peningkatan kemampuan komunikasi matematis siswa kelas eksperimen 2 yang mendapatkan model pembelajaran kooperatif tipe Numbered Head Together (NHT) berdasarkan hasil analisis gain ternormalisasi memperoleh nilai rata-rata 0,58 dengan interpretasi peningkatan sedang.

3. Kemampuan komunikasi matematis antara yang mendapatkan model pembelajaran kooperatif tipe Numbered Head Together (NHT) lebih baik dibandingkan dengan yang menggunakan model pembelajaran Direct Instruction (DI).

\section{DAFTAR PUSTAKA}

Al-Tabany, Trianto. (2017). Mendesain Model Pembelajaran Inovatif, Progresif, dan Kontekstual. Surabaya: PT Kharisma Putra Utama.

Creswell, John A. (2016). Reaserch Design. Yogyakarta : Pustaka Belajar

Departemen Pendidikan Nasional. (2006). Peraturan Menteri Pendidikan Nasional No 22 Tahun 2006 tentang Sistem Pendidikan Nasional. Jakarta: Depdiknas.

Hayati, I. B. (2014). Penerapan Model Treffinger Untuk Meningkatkan Kemampuan Komunikasi Matematis Siswa. Skripsi Juursan Pendidikan Matematika UIN syarif Hidayatullog Jakarta. 1-186. $13 \quad$ November 2018. http://repository.uinjkt.ac.id/dspace/bit stream/123456789/24438/1/Skripsi\%2 0lla\%20Bainatul\%20Hayati.pdf

Hendriana, H Suemarmo, U. 2014. Penilaian Pembelajaran Matematika. Bandung : PT. Refika Aditama

Hibatulloh, B dan Sofyan, D (2014). Perbandingan Kemampuan Matematis Antara Siswa yang mendapatkan model pembelajaran kooperatif tipe Jigsaw dengan Konvensional. Jurnal Pendidikan Matematika. STKIP Garut, 3,3-4

Joyce, Weil, \& Calhoun. (2015). Model of teaching. Yogyakarta : Pustaka Pelajar 
4th National Seminar on Guidance and Counseling (SNBK 2019) and Workshop on

Pedagogical Theory and Practice (WTPP 2019)

SHEs: Conference Series 2 (2) (2019) $184-192$

Komalasari, Kokom. (2015). Pembelajaran Konteksrual. Bandung : PT. Refika Aditama

Lakur, Magur dan Ramdan (2018) Pengaruh Model Pembelajaran Kooperatif Tipe Numbered Head Together (NHT) Terhadap kemampuan komunikasi matematis. Jurnal Pendidikan Matematika STKIP Santo Paulus, Vol 7,3,358-368.

Lestari dan Yudhanegara. (2015). Penelitian Pendidikan Matematika. Bandung : PT. Refika Aditama.

Sinaga, C. (2017). Kemampuan Komunikasi Matematika (Communication

Mathematics Ability, Medan : State Universiti Of Medan 26 December 2019.

https://www.researchgate.net/publicati on/321835644

Sugiono. (2012). Statistika Untuk Penelitian. Bandung : ALFABETA.

Sundayana, Rostiana. (2016). Statistika Penelitian Pendidikan. Garut : STKIP Garut Press

Sukmadinata, Nana Syaodih (2012). Metode Penelitian Pendidikan. Bandung : PT. Remaja Rosdakarya

Walle, John. A. (2008). Matematika Sekolah Dasar dan Menengah Pengembangan Pengajaran. Jakarta:Erlangga

Yahya, N. A (2016). Perbandingan Kemampuan Pemahaman Matematis Antara Siswa Yang Mendapatkan Model Pembelajaran Auditory Intelectually Repetition (Air) Dengan Direct Instruction (DI). Skripsi STKIP Garut 